\title{
Sorafenib in progressive castrate-resistant prostate cancer. Can we talk about a new therapeutic option?
}

Magdalena Zaborowska $a^{1}$, Sebastian Szmit ${ }^{1,2}$, Cezary Szczylik ${ }^{1}$

1Department of Oncology, Military Institute of Medicine, Warsaw, Poland

2First Department of Cardiology, Medical University of Warsaw, Poland

Submitted: 12 September 2010

Accepted: 24 March 2011

Arch Med Sci 2012; 8, 3: 528-532

DOI: 10.5114 /aoms.2012.29408

Copyright (c) 2012 Termedia \& Banach

\section{Abstract}

Castrate-resistant prostate cancer represents a significant clinical challenge. Currently, the standard treatment for patients with castrate-resistant prostate cancer is chemotherapy, after which patients only receive symptomatic treatment. The available results of phase II clinical trials of sorafenib in patients with hormone-refractory prostate cancer indicate that, despite a relatively short progression-free survival, the treatment may be associated with good outcomes in terms of overall survival and maintenance of a good quality of life. The study presents the authors' critical opinions and observations about the usefulness of sorafenib in patients with prostate cancer.

Key words: castrate-resistant prostate cancer, angiogenesis inhibitor, sorafenib.

\section{Introduction}

Clinical observations show that prostate cancer progression usually occurs after 18-24 months of hormone therapy [1]. Also, nearly all docetaxel-treated patients eventually experience disease progression [2, 3]. The median survival in metastatic hormone-refractory prostate cancer is below 12 months, and less than $10 \%$ of patients survive for more than 2 years [4]. The outcome is related to stage of disease, diagnosis usually appear very late, because knowledge regarding symptoms of prostate cancer is still very unsatisfactory [5].

The National Comprehensive Cancer Network (NCCN) guidelines provide no recommendations on prostate cancer treatment following the failure of chemotherapy [6]. In such an advanced stage of disease, symptomatic treatment appeared to be the only choice.

However, an attempt was made to use sorafenib. Sorafenib targets multiple kinases, such as Raf, c-kit, c-Ret, and vascular endothelial growth factor (VEGF) and platelet-derived growth factor (PDGF) receptor tyrosine kinases. Sorafenib inhibits the Raf kinase pathway, thus inhibiting tumour cell proliferation. In addition, it affects VEGF and PDGF receptor tyrosine kinases and their downstream cascades to exert anti-angiogenic effects.

The Raf kinase pathway is impaired in castrate-resistant prostate cancer [7-9]. In prostate cancer, the VEGF-VEGF receptor pathway is important for the growth of primary tumours and for the formation of metastases $[10,11]$. The efficacy of docetaxel was increased when administered with the angiogenesis inhibitors bevacizumab and thalidomide [12].

\author{
Corresponding author: \\ Sebastian Szmit MD, PhD \\ Department of Oncology \\ Military Institute of Medicine \\ 128 Szaserow \\ 04-141 Warsaw, Poland \\ Phone: + 48226103098 \\ Fax: + 48226103098 \\ $1^{\text {st }}$ Department of Cardiology \\ Medical University of Warsaw \\ 1a Banacha \\ 02-097 Warsaw, Poland \\ Phone: + 48225991958 \\ Fax: + 48225991957 \\ E-mail: s.szmit@gmail.com
}


Table I. Results of phase II studies including patients with castrate-resistant prostate cancer treated with sorafenib

\begin{tabular}{|c|c|c|c|}
\hline Author & Patient population & End points & Results of treatment \\
\hline $\begin{array}{l}\text { Steinbild } \\
\text { et al. } 2007 \text { [13] }\end{array}$ & $\begin{array}{l}\text { - } 57 \text { patients } \\
\text { - } \mathrm{ECOG}<2 \\
\text { - } \mathrm{HGB}>9 \mathrm{~g} / \mathrm{dl} \\
\text { - Creatinine } \leq 1.5 \times \text { ULN }\end{array}$ & $\begin{array}{l}\text { Primary objective: } \\
\text { rate of progression-free } \\
\text { survival } \geq 12 \text { weeks } \\
\text { Secondary end points: } \\
\text { - Overall response } \\
\text { - Overall survival } \\
\text { - Toxicity }\end{array}$ & $\begin{array}{l}\text { at } 12 \text { weeks } \\
\text { - } 4 \text { - stable disease (RECIST) } \\
\text { - } 11 \text { - stable disease (PSA-response) } \\
\text { - } 2 \text { - PSA - responders } \\
\text { - The } 1 \text { year PFS rate was } 13 \% \\
\quad(95 \% \text { CI: } 6-28 \%) \\
\text { - The } 1 \text {-year OS rate: } 68 \% \\
\text { (95\% CI: } 56-82 \%)\end{array}$ \\
\hline $\begin{array}{l}\text { Chi et al. } \\
2008 \text { [14] }\end{array}$ & $\begin{array}{l}\text { - } 28 \text { patients } \\
\text { - ECOG: } 0 \text { or } 1 \\
\text { - HGB } \geq 10 \mathrm{~g} / \mathrm{dl} \\
\text { - Creatinine within normal } \\
\text { limits } \\
\text { - Creatinine clearance } \\
\geq 60 \mathrm{ml} / \mathrm{min}\end{array}$ & $\begin{array}{l}\text { Primary end point: } \\
\text { PSA response defined } \\
\text { as } a \geq 50 \% \text { decrease } \\
\text { for } \geq 4 \text { weeks } \\
\text { Secondary end point: } \\
\text { - Measurable disease responses } \\
\text { - PFS and OS }\end{array}$ & $\begin{array}{l}\text { - The PSA response rate was } 3.6 \% \\
\text { - } 5 \text { patients had stable disease } \\
\text { (among } 12 \text { with measurable disease) } \\
\text { - Time to PSA progression was } \\
2.1 \text { months ( } 95 \% \mathrm{Cl} 1.8-6.4) \\
\text { - OS was } 12.25 \text { months } \\
\text { ( } 95 \% \mathrm{Cl} 6.7-16.46)\end{array}$ \\
\hline $\begin{array}{l}\text { Dahut } \\
\text { et al. } 2008 \text { [15] }\end{array}$ & $\begin{array}{l}\text { - } 22 \text { patients } \\
\text { - ECOG: } 0 \text { to } 2 \\
\text { - HGB }-13.05 \mathrm{~g} / \mathrm{dl}(10.2-15.1) \\
\text { - Creatinine }<1.5 \times \text { ULN } \\
\text { - GFR }>60 \mathrm{ml} / \mathrm{min} / 1.73 \mathrm{~m}^{2} \\
\text { - Life expectancy } \\
\text { of } \geq 12 \text { weeks }\end{array}$ & $\begin{array}{l}\text { Primary end point: } \\
\text { disease progression } \\
\text { (RECIST) or increase in PSA } \\
\text { Secondary end point: } \\
\text { - Overall response rate } \\
\text { - Overall survival }\end{array}$ & $\begin{array}{l}\text { - No complete or partial response } \\
\text { was noted } \\
\text { - No patient had a PSA decline } \\
\text { of }>50 \% \\
\text { - The median progression-free survival } \\
\text { duration was } 1.8 \text { months: } \\
-7 \text { patients were progression-free } \\
\text { by PSA criteria at } 4 \text { months } \\
\text { - } 9 \text { of } 14 \text { patients who progressed } \\
\text { at or before } 4 \text { months progressed } \\
\text { only by PSA consensus criteria }\end{array}$ \\
\hline $\begin{array}{l}\text { Aragon-Ching } \\
\text { et al. } 2009 \text { [16] }\end{array}$ & $\begin{array}{l}\text { - } 24 \text { patients } \\
\text { - ECOG: } 0 \text { or } 1 \\
\text { - HGB: } 12.4 \mathrm{~g} / \mathrm{dl}(10.4-14.2)\end{array}$ & $\begin{array}{l}\text { Primary end point: } \\
\text { progression by RECIST criteria } \\
\text { Secondary end point: } \\
\text { - Pharmacokinetics } \\
\text { - Toxicity } \\
\text { - Overall survival }\end{array}$ & $\begin{array}{l}\text { - } 1 \text { patient had a partial response } \\
\text { - } 10 \text { patients had stable disease } \\
\text { - Median duration } 18 \text { weeks } \\
\text { (15-48 weeks) } \\
\text { - Median PFS was } 3.7 \text { months } \\
\text { - Median OS was } 18.0 \text { months }\end{array}$ \\
\hline $\begin{array}{l}\text { Safarinejad } \\
\text { et al. } 2010 \text { [17] }\end{array}$ & $\begin{array}{l}\text { - } 64 \text { patients } \\
\text { - ECOG 0-3 } \\
\text { - HGB } \geq 10 \mathrm{~g} / \mathrm{dl} \text {, } \\
\text { - Creatinine } \leq 2 \mathrm{mg} / \mathrm{dl} \text {, } \\
\text { - Life expectancy } \\
>6 \text { months }\end{array}$ & $\begin{array}{l}\text { Primary end point: } \\
\text { PSA response ( } 50 \% \text { reduction) } \\
\text { Secondary end point: } \\
\text { - Objective measurable disease } \\
\text { responses } \\
\text { - Overall survival (OS) } \\
\text { - Time to progression (TTP) } \\
\text { - Toxicity } \\
\text { - Pain response }\end{array}$ & $\begin{array}{l}\text { Median OS: } 14.6 \text { months (Cl: } 8.2-22.2) \\
\text { Partial response: } \\
\text { • } 7 / 35 \text { patients ( } 20 \% \text { ) with } \\
\text { measurable extraosseous disease } \\
\text { - } 13 / 64 \text { patients ( } 20.3 \% \text { ) achieved } \\
\geq 50 \% \text { reduction in PSA level after } \\
\text { two cycles: } \\
\text { - Median response duration: } \\
2.5 \text { months ( } 95 \% \text { Cl: } 1.4-4.8) \text {, } \\
\text { - Median time to progression: } \\
5.9 \text { months ( } 95 \% \mathrm{Cl}: 3.6-7.6)\end{array}$ \\
\hline
\end{tabular}

Currently, there are published reports in the literature of phase II clinical trials where the efficacy of sorafenib treatment in advanced prostate cancer has been evaluated [13-17] (Table I). The decision to begin sorafenib treatment may be very difficult. The patient may have many coexisting diseases, and their clinical status may be very bad. Many patients would not have a chance of the treatment in these trials, because exclusion criteria were rigorous. For example, patients with significant anaemia and renal failure were not enrolled in any study; the ECOG performance status of the participants was 0 or 1.

\section{Inclusion criteria}

Patients with anaemia and renal failure were not enrolled in any study that evaluated the efficacy of sorafenib treatment. In all such studies, the ECOG performance status of the participants was 0 or 1 , and their haemoglobin levels were above $10 \mathrm{~g} / \mathrm{dl}$ with the exception of one study where the participants had haemoglobin levels above $9 \mathrm{~g} / \mathrm{dl}$ [13]. 
In addition, in all studies, the patients exhibited normal renal function, as demonstrated by creatinine levels of $<1.5 \times$ ULN or $<2 \mathrm{mg} / \mathrm{dl}$. In two studies $[14,15]$, one of the inclusion criteria for the study was that the patients should have a glomerular filtration rate $(\mathrm{GFR})>60 \mathrm{ml} / \mathrm{min} / 1.73 \mathrm{~m}^{2}$.

\section{Prostate-specific antigen (PSA) reduction}

The PSA-based response to treatment has been defined in many different ways. In a study by Safarinejad et al. [17], a complete PSA response was defined as a normalisation of PSA levels to $<4 \mathrm{ng} / \mathrm{ml}$, a partial response was defined as $a \geq 50 \%$ reduction in PSA levels, and progression was defined as $a \geq 50 \%$ increase in PSA levels when compared to baseline. In that study, none of the patients exhibited a complete response to treatment, and 13 of 64 patients $(20.3 \%)$ achieved $a \geq 50 \%$ decrease in PSA levels after 2 cycles of treatment.

Moreover, PSA levels may be good indicators for a positive clinical and radiological response to sorafenib treatment. For comparison, Chi et al. [14] in their study assumed a PSA reduction of $\geq 50 \%$ as the primary end point, and the reported response rate was only $3.6 \%$, and the secondary end point, time to progression, was only 2.1 months.

Similarly, Steinbild et al. [13] reported that only 2 of 57 patients achieved a response to treatment in terms of PSA levels, and 11 other patients achieved disease stabilisation. In another study, Dahut et al. [15] reported that PSA levels may not be a good indicator for the relationship between clinical and radiological responses to sorafenib treatment. In addition, none of the patients who participated in that study achieved a PSA reduction of $>50 \%$, while 21 of 22 experienced disease progression and 13 exhibited increases in PSA levels. In addition, in 9 of 14 patients with progression before 4 months of treatment with sorafenib, the progression status was only determined by PSA levels.

\section{RECIST response}

In the field of oncology, assessment of cancer metastases according to the RECIST (Response Evaluation Criteria In Solid Tumors) guidelines [18] is considered the most important. These criteria allow physicians to rule out or confirm the growth of metastatic lesions in solid organs. However, this method has limitations, especially for evaluation of the efficacy of angiogenesis inhibitors such as sorafenib. Inhibition of angiogenesis causes a cytostatic effect (i.e., tumour growth inhibition) and not a cytotoxic effect (i.e., tumour regression). Some of the early results of anti-angiogenic therapy may include oedema around a tumour site. If such a result is misinterpreted, it may suggest tumour progression. Another problem in the assessment of a patient's response to treatment is the issue of whether we should only take into account the largest dimension of the tumour, which is measured on a plane. Measurement of tumour volume would be more precise. Especially, the growth of metastatic lesions in the liver should be assessed carefully.

In a study by Chi et al. [14], only 5 of 12 patients with measurable tumours achieved disease stabilisation. In another study by Steinbild et al. [13], only 4 of 57 patients achieved stabilisation according to the RECIST guidelines. Aragon-Ching et al. [14] reported that out of 24 patients, one achieved a partial response to treatment and 10 had stable disease. The best outcomes were reported in a study by Safarinejad et al. [17] where as many as 7 of 35 patients (20\%) with measurable tumours exhibited partial responses to treatment.

\section{Bone metastases and pain}

It is worth noting that only one study evaluated the efficacy of sorafenib treatment in terms of pain [16]. In that study, the reduction of PSA levels correlated with pain reduction in 5 patients (7.8\%) after two cycles of treatment and in 10 other patients (15.6\%) after four cycles of treatment. Among these 15 patients, 8 were receiving high doses of morphine; at follow-up, 3 patients no longer required morphine treatment, and the dose of morphine was reduced by $75 \%$ in another 3 patients. The mean duration of pain reduction was 114 days (91-171 days). Our patient reported a significant reduction of pain that has been maintained for at least 8 months, which is significantly longer than previously reported.

It is worth emphasising that in the study by Chi et al. [14], the use of high-dose narcotic analgesics, such as $>30 \mathrm{mg} /$ day morphine, was considered as a criterion for exclusion from the study.

\section{Progression-free and overall survival}

From the phase II clinical trials that have evaluated the efficacy of sorafenib, we conclude that hormone-refractory prostate cancer is characterised by a short progression-free survival (PFS) with rather good overall survival (OS). Steinbild et al. [13] reported that the probability of 1-year PFS in prostate cancer patients was only $13 \%(95 \% \mathrm{Cl}$ : $6-28 \%)$ but that the chances of surviving 1 year were as high as $68 \%(95 \% \mathrm{Cl}: 56-82 \%)$. AragonChing et al. [16] reported that the median PFS in these patients was 3.7 months, and the median OS was 18 months. In contrast, Dahut et al. [15] found that median PFS was only 1.8 months. In addition, Safarinejad et al. [17] reported that the median PFS was 5.9 months $(95 \% \mathrm{Cl}: 3.6-7.6)$ and the median OS was 14.6 months ( $95 \% \mathrm{Cl}: 8.2-22.2)$, whereas 
Chi et al. [14] reported a PSA-based PFS of 2.1 months (95\% Cl: 1.8-6.4) and an OS of 12.25 months (95\% Cl: 6.7-16.46).

\section{Sorafenib toxicity}

Sorafenib is well tolerated by patients. The toxicity of sorafenib has only been evaluated in three phase II clinical trials $[13,16,17]$. The results of these studies show that some complications could impair the patients' quality of life. In the study conducted by Safarinejad et al. [17], the most common adverse events experienced by the patients were diarrhoea (40.6\%), rash/desquamation (39.1\%), fatigue (35.9\%), hand-foot syndrome (32.8\%), alopecia (31.3\%) and nausea (26.6\%). Hypertension only occurred in $3.1 \%$ of the patients. In the study conducted by Aragon-Ching et al. [16], adverse effects were reported by more than $10 \%$ of the patients. These adverse effects included hand-foot syndrome (3 grade 3 cases and 9 grade 2 cases in 24 patients), rash/desquamation (11 grade 1 cases and 3 grade 2 cases) and fatigue (12 grade 1 or 2 cases and 2 grade 3 cases). Steinbild et al. [13] reported that the most common adverse events experienced by the patients were skin lesions (16 of 57 patients), fatigue (13 patients), diarrhoea (10 patients) and hypertension (9 patients).

Hypertension seems to be a class effect of angiogenesis inhibitors. It is a safe complication of sorafenib treatment that can be very efficiently treated. We should remember some cardiologic drugs are cytochrome P450 inhibitors and they can significantly reduce the efficacy of sorafenib $[19,20]$.

\section{Own critical observations}

In everyday clinical practice there are many young men with advanced castrate-resistant prostate adenocarcinoma, who experienced progression of disease during docetaxel-based chemotherapy. Researchers and experts discuss the use of angiogenesis inhibitors in such patients. The authors observed significant positive clinical and biochemical changes related to sorafenib, this improvement being correlated with the results of the radiological examinations, which according to the RECIST guidelines indicates that the patient was cancer progression-free. At baseline, the patient had an ECOG 3 clinical condition, was diagnosed with steroid therapy-induced diabetes and stage 3 chronic kidney disease, had recurring urosepsis and a right nephrostomy, and was placed on intensive analgesic treatment. During 8 months of treatment with sorafenib, we observed a significant improvement in the patient's biochemical response; he had a $14 \%$ reduction in PSA levels after 4 weeks of treatment and a $57.35 \%$ reduction after 3 months, after which the PSA levels remained relatively constant.
At the same time, we observed a significant improvement in blood cell counts, the haemoglobin levels remained constant, and blood transfusions were no longer required. As a result of sorafenib treatment, the patient's renal function significantly improved. Therefore, the right nephrostomy was removed, and it was replaced with a double-J urethral catheter. Over the course of 8 months of treatment with sorafenib, the patient had only had one episode of urinary tract infection. The stabilisation of the metastatic lesions in his skeletal system significantly reduced his bone pain. This patient has already achieved a significantly better PFS and quality of life.

In general, remarkable results can be seen with every drug if used for a non-approved indication. If 100 patients are treated there will be 1 or 2 responding just by chance. We would like to add real knowledge to the already existing literature. Therefore we would like to perform Polish multicentre research in this area of interest. This paper would be a first step to discuss which subgroup of patients with castrate-resistant prostate cancer can achieve a real advantage from treatment with sorafenib.

\section{Conclusions}

The phase II clinical trials with sorafenib in prostate cancer did not give spectacular results. We believe that sorafenib could be one of some new options following the failure of chemotherapy in this disease. Additional well-designed studies are necessary to evaluate a subgroup of patients with prostate cancer who may experience significant improvement after sorafenib therapy.

\section{References}

1. Crawford ED, Eisenberger MA, McLeod DG, et al. A controlled trial of leuprolide with and without flutamide in prostatic carcinoma. N Engl J Med 1989; 321: 419-2.

2. Tannock IF, de Wit R, Berry WR, et al. TAX 327 Investigators. Docetaxel plus prednisone or mitoxantrone plus prednisone for advanced prostate cancer. N Engl J Med 2004; 351: 1502-12.

3. Safarinejad MR. Combination chemotherapy with docetaxel, estramustine, and suramin for hormone refractory prostate cancer. Urol Oncol 2005; 23: 93-101.

4. Raghavan D, Brandes LJ, Klapp K, et al. Phase II trial of tesmilifene plus mitoxantrone and prednisone for hormone refractory prostate cancer: high subjective and objective response in patients with symptomatic metastases. J Urol 2005; 174: 1808-3.

5. Kozłowska E, Szewczyk MT, Banaszkiewicz Z, Jawień A, Cierzniakowska K, Jarmocik P. Knowledge of symptoms and diagnostic possibilities of cancer diseases. Arch Med Sci 2011; 7: 304-9.

6. National Comprehensive Cancer Network Clinical Practice Guidelines in Oncology: Prostate Cancer v1.2011, www.ncen.org.

7. Erlich S, Tal-Or P, Liebling R, et al. Ras inhibition results in growth arrest and death of androgen-dependent and 
androgen-independent prostate cancer cells. Biochem Pharmacol 2006; 72: 427-36.

8. Gioeli D, Mandell JW, Petroni GR, Frierson HF Jr, Weber MJ. Activation of mitogen activated protein kinase associated with prostate cancer progression. Cancer Res 1999; 59: 279-84.

9. Gioeli D. Signal transduction in prostate cancer progression. Clin Sci Lond 2005; 108: 293-308.

10. Brawer MK, Deering RE, Brown M, Preston SD, Bigler SA. Predictors of pathologic stage in prostatic carcinoma. The role of neovascularity. Cancer 1994; 73: 678-87.

11. Bettencourt MC, Bauer JJ, Sesterhenn IA, Connelly RR, Moul JW. CD34 immunohistochemical assessment of angiogenesis as a prognostic marker for prostate cancer recurrence after radical prostatectomy. J Urol 1998; 160: 459-65.

12. Ning YM, Gulley JL, Arlen PM, et al. Phase II trial of bevacizumab, thalidomide, docetaxel, and prednisone in patients with metastatic castration-resistant prostate cancer. J Clin Oncol 2010; 28: 2070-6.

13. Steinbild S, Mross K, Frost A, et al. A clinical phase II study with sorafenib in patients with progressive hormonerefractory prostate cancer: a study of the CESAR Central European Society for Anticancer Drug Research-EWIV. Br J Cancer 2007; 97: 1480-5.

14. Chi KN, Ellard SL, Hotte SJ, et al. A phase II study of sorafenib in patients with chemo-naive castrationresistant prostate cancer. Ann Oncol 2008; 19: 746-51.

15. Dahut WL, Scripture C, Posadas E, et al. A phase II clinical trial of sorafenib in androgen-independent prostate cancer. Clin Cancer Res 2008; 14: 209-14.

16. Aragon-Ching JB, Jain L, Gulley JL, et al. Final analysis of a phase II trial using sorafenib for metastatic castrationresistant prostate cancer. BJU Int 2009; 103: 1636-40.

17. Safarinejad MR. Safety and efficacy of sorafenib in patients with castrate resistant prostate cancer: a phase II study. Urol Oncol 2010; 28: 21-7.

18. Therasse P, Arbuck SG, Eisenhauer EA, et al. New guidelines to evaluate the response to treatment in solid tumors. European Organization for Research and Treatment of Cancer, National Cancer Institute of the United States, National Cancer Institute of Canada. J Natl Cancer Inst 2000; 92: 205-16.

19. Kollmannsberger C, Soulieres D, Wong R, et al. Sunitinib therapy for metastatic renal cell carcinoma: recommendations for management of side effects. Can Urol Assoc J 2007; 1 (2 Suppl): S41-54.

20. Maitland ML, Bakris GL, Black HR, et al. Cardiovascular Toxicities Panel, Convened by the Angiogenesis Task Force of the National Cancer Institute Investigational Drug Steering Committee. Initial assessment, surveillance, and management of blood pressure in patients receiving vascular endothelial growth factor signaling pathway inhibitors. J Natl Cancer Inst 2010; 102: 596-604. 